\title{
Argali and Siberian Ibex Populations in the Khuhsyrh Reserve in Mongolian Altai
}

\author{
Ryszard DZIĘCIOŁOWSKI, Jerzy KRUPKA, BAJANDELGER \\ \& Roman DZIEDZIC
}

\begin{abstract}
Dzięciołowski R., Krupka J., Bajandelger \& Dziedzic R., 1980: Argali and Siberian ibex populations in the Khuhsyrh Reserve in Mongolian Altai. Acta theriol., 25, 16: 213-219 [With 3 Tables \& 1 Fig.].

Two expeditions organized in February and August 1979 to the reserve (83.5 thous.ha) investigated the present status of both populations in what is meant a prime habitat for these animals in Mongolia. Argali population was estimated on ca 600 individuals. Sex ratio amounted to $1: 1.5$ on the favour of females in summer, while in winter it rose to $1: 2$. The population had following structure: $28 \%$ rams, $41 \%$ ewes and $31 \%$ lambs in summer and $38 \%$ rams, $45 \%$ ewes and $17 \%$ lambs in winter. Realized increment amounted to 16 lambs per 100 females. Mean density varied from 1.2 animals $/ \mathrm{km}^{2}$ in summer to $0.8 / \mathrm{km}^{2}$ in winter. Ibex population was estimated on ca 1,000 animals. Sex ratio varied from 1:2 in summer to $1: 2.2$ in winter. The population had following structure: $21 \%$ males, $45 \%$ females and $34 \%$ kids in summer and $21 \%$ males, $46 \%$ females and $33 \%$ kids in winter. Realized increment amounted to 71 fawns per 100 females in February. Mean density of ibex population was $1.0 / \mathrm{km}^{2}$ throughout a year. Both species are gregarious, the most important aggregations being herds of dams with kids during summer and mixed ones during winter. Each of the species studied reveals different habitat preferences. Argali prefer grassy areas that are not too steep, while ibex - rougher, more precipitous slopes.
\end{abstract}

[Forestry Res. Inst., Wery Kostrzewy 3, 02-362 Warszawa, Poland].

\section{INTRODUCTION}

On September 14, 1978, the C.I.C. (Conseil International de la Chasse) signed an agreement with the Ministry of Forestry and Woodworking Industries, Mongolian People's Republic, on the establishment and research to be done in the Khuhsyrh Reserve. The reserve includes prime habitat of two most important wild ungulates in Asiatic mountains, namely: argali sheep, Ovis ammon Linnae us, 1758 and Siberian ibex, Capra ibex sibirica ( $\mathrm{P}$ a 11 a s, 1776). It extends over the main range of Mongolian Altai, its highest peak elevating at 4,019 m above the sea level. The area of the reserve covers some 83,500 ha. For detailed location see Figs. 1 and 2. It is situated within the Kobdo aymak and Kobdo somon, with coordinates $\mathrm{E} 90^{\circ} 53^{\prime}$ to $91^{\circ} 18^{\prime}$, N $47^{\circ} 40^{\prime}$ to $48^{\circ} 05^{\prime}$. 
The reserve is situated within semi-desert and Alpine biomes with plant formations typical for them. Mountains are completely deprived of forests. Peaks and tops of ridges are rocky with only sparse tufts of grasses. Slopes are covered with dwarf shrubs of Caragana sp. and dry grasses during winter. It is only in valleys, along streams, where single trees of poplar (Populus diversifolia) and shrubs of willows (Salix sp.) are to be found.

The main purpose of the creation of the reserve was to provide protection for the two ungulate species mentioned.

\section{PURPOSE AND PROCEDURE OF WORK}

The purpose of expeditions was to investigate the present status of argali sheep and Siberian ibex populations in what was meant a prime habitat of these animals in Mongolia.

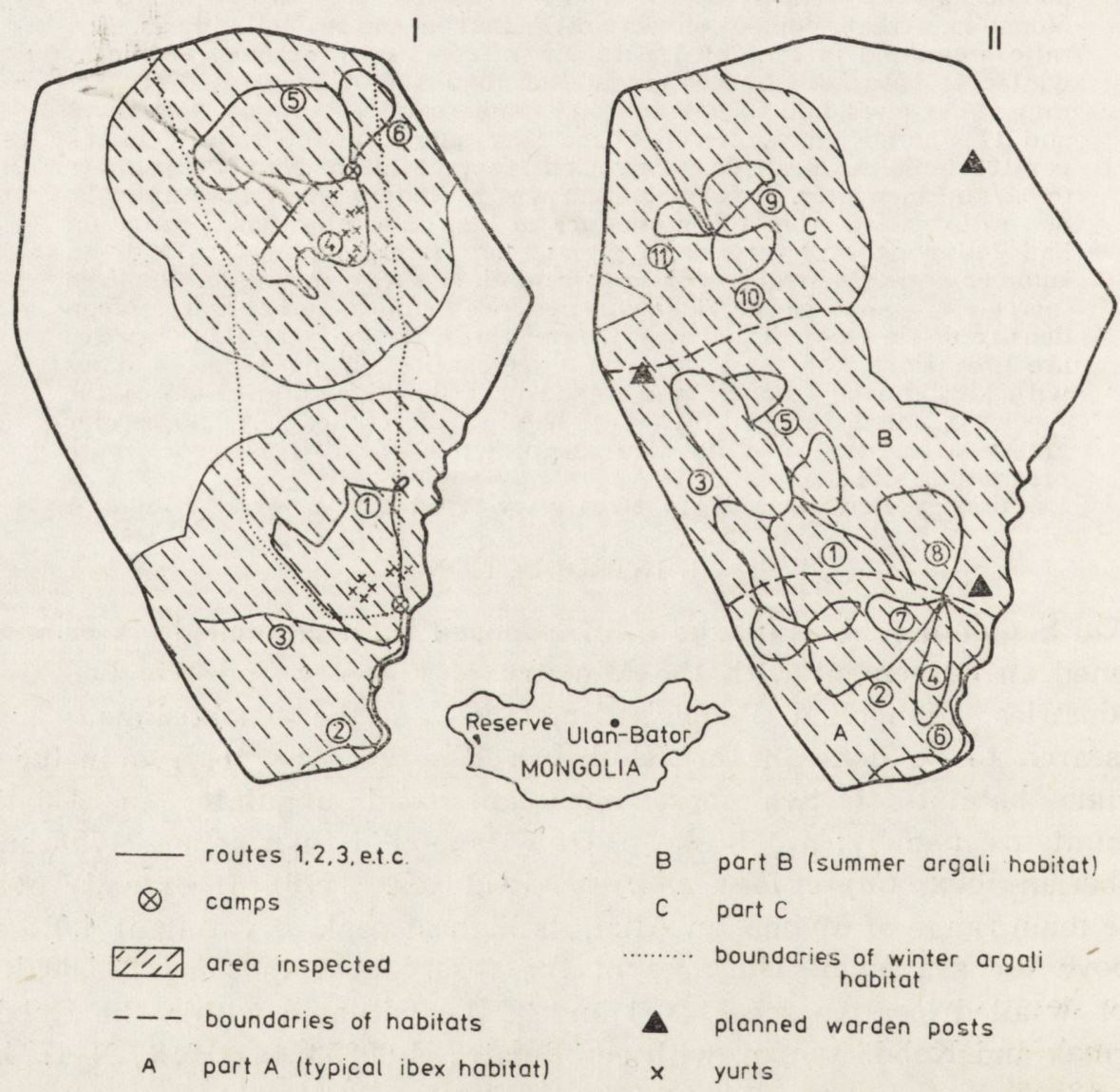

Fig. 1. The reserve with winter (I) and summer (II) census routes. 
The work was done by horse-riding, vehicle driving or walking along prescribed routes and observing animals with the aid of field-glasses and telescope. Whenever possible the sex and age (adult - juvenile) ratios of aggregations encountered were determined. The location of herds was also identified. All information was recorded on tape-recorders in field and put into notes same day after returning to camp. In the course of expeditions two camps were utilized: one in the southern end and the other in the northern part of the reserve. Besides, three bivouacs were utilized while visiting the western part of the reserve. From each camp or bivouac several trips were done along different routes (see Fig. 1; I, II).

During each trip there have been taken also observations on human disturbance (number of herds of camels, yaks, cattle, horses, goats and sheep, number of yurts, etc.), as well as on other animals and their tracks.

Field work was done in the course of two expeditions: on February $1-20$ and August 9-28, 1979 under favourable weather conditions. Air temperatures ranged from $-20^{\circ} \mathrm{C}$ at night to $0^{\circ} \mathrm{C}$ during a day in February and from $-4^{\circ} \mathrm{C}$ at night to $+20^{\circ} \mathrm{C}$ during a day in August. In February snow occurred only in small patches on northern slopes and high peaks (above 3 thous.m a.s.1.), while in August - above 3.5 thous.m a.s.l. Occasional gale and intermittent snowfall were experienced both in February and in August.

\section{RESULTS}

\section{a. Numbers and Density}

Total area of the reserve equals $855.8 \mathrm{~km}^{2}$ and $573.3 \mathrm{~km}^{2}(68.6 \%)$ was surveyed in February and $545.2 \mathrm{~km}^{2}(65.2 \%)$ in August. Results of censuses are given in Table 1. Altogether in February 242 argali and 748 ibexes were seen, while in August 667 argali and 539 ibexes. Results given in Table 2 illustrate the density of both populations in the surveyed part of the reserve. The mean density was $0.8-1.2$ animals $/ \mathrm{km}^{2}$ for argali and $1.0 / \mathrm{km}^{2}$ for ibex. It varied in different habitats. In the habitat typical for ibex (southern part of the reserve) their density attained from 3.3 (winter) to $4.8 / \mathrm{km}^{2}$ in summer with a virtual absence of argali. On the other hand in the central part of the reserve, constituting argali habitat, their density was $2.0 / \mathrm{km}^{2}$ during winter and $2.3 / \mathrm{km}^{2}$ during summer, while that of ibex varied from $0.9 / \mathrm{km}^{2}$ during winter to $0.4 / \mathrm{km}^{2}$ during summer. Joint density of both herbivore species amounted to 1.8 animals $/ \mathrm{km}^{2}$ in winter and 2.2 animals $/ \mathrm{km}^{2}$ in summer.

\section{b. Population Structure and Herd Performance}

Analysis of sex and age structure of populations studied was possible for $86.8 \%$ of argali and $80.0 \%$ of ibex encountered in winter and for only $43 \%$ of argali and $33.2 \%$ of ibex observed during summer. This indicates much poorer conditions for observations in summer when compared to winter. 
Sex ratio in the summer argali population amounted to $1: 1.5$ on the favour of females, while in winter it raised to $1: 2$. It may be even more skew, when one will add 412 unclassed animals (see Table 1), among which no adult males were observed.

The population structure reveals: summer $-28 \%$ rams, $41 \%$ ewes and $31 \%$ lambs; winter $-38 \%$ rams, $45 \%$ ewes and $17 \%$ lambs. Realized increment decreased from 75 lambs per 100 females in August to 16 lambs per 100 females in February.

Table 1

Numbers, sex and age structure of argali and ibex recorded along 6 routes in February and 11 routes in August.

\begin{tabular}{lrrrrr}
\hline & Total & Males & Females & Juveniles & Unclassed \\
\hline \multicolumn{7}{c}{ ARGALI } \\
February & 242 & 49 & 139 & 22 & 32 \\
August & 667 & 80 & 118 & 89 & 380 \\
$\quad$ Total & 909 & 129 & 257 & 111 & 412 \\
Mean & 454 & 64 & 128 & 56 & 206 \\
& & \multicolumn{7}{c}{ IBEX } & & \\
February & 748 & 125 & 276 & 197 & 150 \\
August & 539 & 115 & 41 & 23 & 360 \\
$\quad$ Total & 1287 & 240 & 317 & 220 & 510 \\
Mean & 643 & 120 & 158 & 110 & 255 \\
\hline
\end{tabular}

Table 2

Winter and summer density of argali and ibex in Khuhsyrh reserve.

\begin{tabular}{|c|c|c|c|c|c|c|}
\hline \multirow[b]{2}{*}{ Species } & \multirow[b]{2}{*}{ Season } & \multirow{2}{*}{$\begin{array}{l}\text { Total } \\
\text { number }\end{array}$} & \multicolumn{4}{|c|}{ Density: animals $/ \mathrm{km}^{2}$} \\
\hline & & & $\begin{array}{l}\text { Southern } \\
\text { part }\end{array}$ & $\begin{array}{l}\text { Central } \\
\text { part }\end{array}$ & $\begin{array}{l}\text { Northern } \\
\text { part }\end{array}$ & $\begin{array}{l}\text { Throughout } \\
\text { the reserve }\end{array}$ \\
\hline \multirow[t]{2}{*}{ Argali } & Summer & 667 & - & 2.3 & - & 1.2 \\
\hline & Winter & 242 & - & 2.0 & 0.3 & 0.8 \\
\hline \multirow[t]{2}{*}{ Ibex } & Summer & 539 & 4.8 & 0.4 & - & 1.0 \\
\hline & Winter & 748 & 3.3 & 0.9 & 1.1 & 1.0 \\
\hline
\end{tabular}

Sex ratio in the summer ibex population amounted to $1: 0.4$ on the favour of males. It would be $1: 2$ on the favour of females, when one adds 360 unclassed animals consisting of dams with kids. In winter the sex ratio amounted to $1: 2.2$ on the favour of females. It may well exceed the ratio of $1: 3$, when one adds 150 unclassified animals consisting of females and juveniles.

The population structure was following: summer $-21 \%$ males, $45 \%$ females and $34 \%$ kids; winter $-21 \%$ males, $46 \%$ females and $33 \%$ kids. Realized increment was estimated on 56 fawns per 100 
females during summer and, curious enough, 71 fawns per 100 females during winter.

Table 3 gives some insight into the herd structure of both species. It results from it that both species lead a gregarious life. Average size of aggregations is rather similar for both species; it varies from 15 to 39 heads. Single animals were observed only sporadically. Most important kinds of aggregations for both species were: herds of dams with kids during summer (aggregating ca $2 / 3$ of each population) and mixed herds during winter. Groups of males were more numerous

Table 3

Characteristics of herd composition.

\begin{tabular}{|c|c|c|c|c|c|c|}
\hline $\begin{array}{l}\text { Type of } \\
\text { herd }\end{array}$ & $\begin{array}{l}\text { Season } \\
\text { of year }\end{array}$ & $\begin{array}{l}\text { No. of } \\
\text { animals }\end{array}$ & $\begin{array}{l}\text { No. of } \\
\text { herds }\end{array}$ & $\begin{array}{l}\text { Animals } \\
\text { per herd }\end{array}$ & Min. - Max. & $\begin{array}{l}\text { Proportion } \\
\text { of animals } \\
\text { in herd }\end{array}$ \\
\hline & & & ARGALI & & & \\
\hline \multirow[t]{2}{*}{ All herds } & Summer & 667 & 17 & 39 & $2-200$ & 100.0 \\
\hline & Winter & 242 & 9 & 27 & $1-105$ & 100.0 \\
\hline \multirow[t]{2}{*}{ Mixed } & Summer & 160 & 1 & 160 & - & 24.0 \\
\hline & Winter & 136 & 2 & 68 & $31-105$ & 56.2 \\
\hline Dams with & Summer & 438 & 10 & 44 & $3-200$ & 65.7 \\
\hline kids & Winter & 83 & 4 & 21 & $14-37$ & 34.3 \\
\hline \multirow[t]{2}{*}{ Females } & Summer & 8 & 1 & 8 & - & 1.2 \\
\hline & Winter & 1 & 1 & 1 & - & 0.0 \\
\hline \multirow[t]{3}{*}{ Males } & Summer & 61 & 5 & 12 & $2-28$ & 9.1 \\
\hline & Winter & 22 & 2 & 11 & $7 \multimap 15$ & 9.1 \\
\hline & & & IBEX & & & \\
\hline \multirow{2}{*}{ All herds } & Summer & 539 & 37 & 15 & $1-78$ & 100.0 \\
\hline & Winter & 748 & 26 & 29 & $1-111$ & 100.0 \\
\hline \multirow[t]{2}{*}{ Mixed } & Summer & 78 & 1 & 78 & - & 14.5 \\
\hline & Winter & 550 & 13 & 42 & $3-111$ & 73.5 \\
\hline Dams with & Summer & 355 & 21 & 17 & $3-73$ & 65.8 \\
\hline kids & Winter & 175 & 8 & 22 & $5-60$ & 23.4 \\
\hline \multirow[t]{2}{*}{ Females } & Summer & 3 & 1 & 3 & 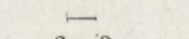 & 0.5 \\
\hline & Winter & 5 & 2 & 2 & $2-3$ & 0.0 \\
\hline \multirow[t]{2}{*}{ Males } & Summer & 103 & 14 & 7 & $1-39$ & 19.1 \\
\hline & Winter & 18 & 3 & 6 & $1-9$ & 2.4 \\
\hline
\end{tabular}

(11-12 rams on average) in argali, where they accounted for more than $9 \%$ of population during both seasons. In ibex these were less numerous ( $6-7$ bucks on average) and more common during summer, when they aggregate above $19 \%$ of the population.

\section{DISCUSSION}

Our estimation of the total population of argali and Siberian ibex within the Khuhsyrh reserve is ca 600 argali and 1,000 ibex. This gives the ratio of 1 argali to 1.6 ibex, rather deviating from the ratio 
of $1: 4$ cited by Bannik ov (1954) for the Gobi Altai. The ratio given by Bannikov was calculated, however, for the material several times less numerous than ours.

Observation conditions were better in February than in August. Much greater proportion of animals fell to the unclassed category in summer than during the winter count. The presence of about 20 yurts with ca 20 thous. domestic animals (camels, horses, yaks, cattle, sheep, and goats) within the reserve during summer ousted argali and ibex to the highest, hardly accessible parts of mountains, where conditions for observation were difficult.

There is "sheep ground" and there is "goat ground " $(\mathrm{Clar} \mathrm{k}, 1970)$. Both types of habitat are to be found in Khuhsyrh reserve. Sheep ground are grassy areas that are not too steep. These will be found on the sunny side of the mountains, on the lofty open slopes with near-by outcrops of rocks which provide for a quick getaway in case of a surprise attack. Sheep habitat cover the central part of the reserve (see Fig. 1). Mountain range along its western boundary and in the southern tip is inaccessible for them under winter conditions, while the eastern part is intensively penetrated by humans with herds of their domestic animals. Argali, similarly as bighorns in North America (De Forge, 1976) indicate a stress imposed by man's impact. Stress appears to be a major limiting factor in the argali's struggle for survival. The adaptations of the wild sheep have been highly successful, evolving basically outside the influence of man. This ice age mammal has become very specialized. It is this specialization and man that is testing its survival today.

Goat ground, on the other hand, is on the rougher, more precipitous slopes, which are also backed by rocky outcrops. Here wild goats find the coarser vegetation which they seem to prefer, leaving the shorter, sweet grass to the sheep. The southern portion of the reserve provides a prime habitat for wild goats.

According both to observations taken in the course of two expeditions, opinions of local residents and evidence from literature (G e i s t, 1974), big predators (snow leopard and wolf), although present in the reserve, are not a serious threat to game animals. One can expect also that the withdrawal of livestock from the reserve will result in a decline of wolf population in that area.

\section{REFERENCES}

1. Bannikov A. G., 1954: Mlekopitajuščie Mongoliskoj Narodnoj Respubliki. Izd. Akad. Nauk SSSR: 1-669. Moskwa. 
2. Clark J. L., 1970: The Great Arc of the Wild Sheep. Univ. of Oklahoma Press: 1-247. Norman.

3. De F or g e J. R., 1976: Stress: is it limiting bighorn? Desert Bighorn Council 1976 Transactions: $30-31$.

4. Ge ist V., 1974: Mountain Sheep. A Study in Behavior and Evolution. The University of Chicago Press: 1-383. Chicago, London.

Accepted, November 14, 1979.

Ryszard DZIĘCIOEOWSKI, Jerzy KRUPKA, BAJANDELGER i Roman DZIEDZIC

POPULACJE ARGALA I KOZIOROŻCA SYBERYJSKIEGO W REZERWACIE KHUHSYRH W MONGOLSKIM AETAJU

\section{Streszczenie}

W 1978 r. utworzono w Mongolii rezerwat argali, Ovis ammon Linnae us. 1758 i koziorożców syberyjskich, Capra ibex sibirica (P a 11 a s, 1776) w głównym masywie Mongolskiego Ałtaju. W obrębie rezerwatu znalazło się 83,5 tys. ha środowiska obydwóch wymienionych gatunków. Celem ekspedycji przeprowadzonych w lutym i sierpniu 1979 r. było oszacowanie liczebności pogłowia argali i koziorożców w rezerwacie.

Inwentaryzację przeprowadzono wzdluż 6 tras $w$ lutym i 11 tras $w$ sierpniu (Ryc. 1). Objęto nią blisko $69 \%$ powierzchni rezerwatu w lutym i ponad $65 \%$ w sierpniu. Stwierdzono obecność 242 argali i 748 koziorożców zimą oraz 667 argali i 539 koziorożców latem (Tabela 1). Srednie zagęszczenie argali w rezerwacie wynosiło $0,8 / \mathrm{km}^{2}$ zimą i $1,2 / \mathrm{km}^{2}$ latem (Tabela 2). Średnie zagęszczenie koziorożców wynosiło $1,0 / \mathrm{km}^{2}$ w obydwóch porach roku. Łączne zagęszczenie obydwóch roślinożerców wynosiło 2,2 latem a $1,8 / \mathrm{km}^{2}$ - zimą. Nie było ono, rzecz jasna, równomierne. W najlepszym środowisku argali (środkowa część rezerwatu) osiągało 2,0-2,3 argale $/ \mathrm{km}^{2}$, natomiast w najlepszym środowisku koziorożców (południowa część rezerwatu) - nie mniej niż $3,3-4,8$ sztuk/ $\mathrm{km}^{2}$.

Stwierdzono wyraźne preferencje środowiskowe $u$ badanych gatunków. Argale preferują niezbyt strome powierzchnie trawiaste, zwłaszcza na poludniowych stokach, natomiast koziorożce - strome urwiska porośnięte krzewami Caragana sp. Wytyczono zasięgi zimowego i letniego środowiska argali w obrębie rezerwatu oraz typowe środowisko koziorożców.

Populacja argali wykazywała: (1) stosunek plei od 1:1,5 latem do 1:2 zimą, (2) strukturę - $28 \%$ tryków, $41 \%$ owiec i $31 \%$ jagniąt latem oraz $38 \%$ tryków, $45 \%$ owiec i $17 \%$ jagniąt zimą oraz (3) przyrost zrealizowany 16 jagniąt na 100 samic w lutym. Populacja koziorożców wykazywała: (1) stosunek płci od 1:2 latem do 1:2,2 zimą, (2) strukturę - 21\% capów, $45 \%$ kóz i $34 \%$ koźląt latem oraz $21 \%$ capów, $46 \%$ kóz i $33 \%$ koźląt zimą oraz (3) przyrost zrealizowany 71 koźląt na 100 samic w lutym. Obydwa gatunki są zwierzętami stadnymi, przy czym najważniejszymi ugrupowaniami latem były stada samic z młodzieżą, natomiast zimą - stada mieszane (Tabela 3). Wyniki inwentaryzacji dały podstawę do oszacowania liczebności argali w rezerwacie na ca 600 a koziorożców - na około 1.000 sztuk. 